University of Nebraska - Lincoln

DigitalCommons@University of Nebraska - Lincoln

USDA National Wildlife Research Center - Staff Publications
U.S. Department of Agriculture: Animal and Plant Health Inspection Service

2011

\title{
Anthraquinone repellent to reduce take of non-target birds from zinc phosphide rodenticide applications
}

\author{
Scott J. Werner \\ USDA/APHIS/ WS/ National Wildlife Research Center, scott.j.werner@aphis.usda.gov \\ Shelagh K. Tupper \\ USDA-APHIS, Wildlife Services' National Wildlife Research Center, shelagh.t.deliberto@usda.gov \\ Susan E. Pettit \\ USDA-APHIS, Wildlife Services' National Wildlife Research Center \\ James C. Carlson \\ USDA/APHIS/WS National Wildlife Research Center, james.c.carlson@aphis.usda.gov \\ George M. Linz \\ USDA/APHIS/WS National Wildlife Research Center, george_m_linz@yahoo.com
}

Follow this and additional works at: https://digitalcommons.unl.edu/icwdm_usdanwrc

Werner, Scott J.; Tupper, Shelagh K.; Pettit, Susan E.; Carlson, James C.; and Linz, George M., "Anthraquinone repellent to reduce take of non-target birds from zinc phosphide rodenticide applications" (2011). USDA National Wildlife Research Center - Staff Publications. 1378.

https://digitalcommons.unl.edu/icwdm_usdanwrc/1378

This Article is brought to you for free and open access by the U.S. Department of Agriculture: Animal and Plant Health Inspection Service at DigitalCommons@University of Nebraska - Lincoln. It has been accepted for inclusion in USDA National Wildlife Research Center - Staff Publications by an authorized administrator of DigitalCommons@University of Nebraska - Lincoln. 


\title{
Anthraquinone repellent to reduce take of non-target birds from zinc phosphide rodenticide applications
}

\author{
Scott J. Werner ${ }^{\mathrm{a}, *}$, Shelagh K. Tupper ${ }^{\mathrm{a}}$, Susan E. Pettit ${ }^{\mathrm{a}}$, James C. Carlson ${ }^{\mathrm{a}}$, George M. Linz ${ }^{\mathrm{b}}$ \\ a United States Department of Agriculture, Animal and Plant Health Inspection Service, Wildlife Services, National Wildife Research Center, 4101 LaPorte \\ Avenue, Fort Collins, CO 80521-2154, USA \\ b United States Department of Agriculture, Animal and Plant Health Inspection Service, Wildlife Services, National Wildife Research Center, North Dakota \\ Field Station, 2110 Miriam Circle, Bismarck, ND 58501-2502, USA
}

\section{A R T I C L E I N F O}

\section{Article history:}

Accepted 15 September 2011

Available online 14 October 2011

\section{Keywords:}

Branta canadensis

Chemical repellent

Cynomys ludovicianus

Eremophila alpestris

Feeding behavior

Phasianus colchicus

\begin{abstract}
A B S T R A C T
We evaluated anthraquinone as an avian repellent to reduce take of non-target birds from zinc phosphide rodenticide applications. We observed zero mortalities and no overt signs of zinc phosphide toxicosis among 20 Canada geese (Branta canadensis), 24 horned larks (Eremophila alpestris), and 47 ring-necked pheasants (Phasianus colchicus) offered baits treated with $1 \%$ or $2 \%$ anthraquinone and $2 \%$ zinc phosphide (target concentrations; wt/wt) during laboratory performance experiments. Thus, anthraquinone successfully prevented consumption of $2 \%$ zinc phosphide baits among non-target birds in captivity. We observed $10 \%$ mortality among black-tailed prairie dogs (i.e., target rodent; Cynomys ludovicianus) offered oats treated with $1 \%$ anthraquinone and $2 \%$ zinc phosphide, and $30 \%$ mortality among blacktailed prairie dogs offered oats treated with $2 \%$ anthraquinone and $2 \%$ zinc phosphide. Upon completion of our experiments, chemical analyses indicated that actual concentrations were $1.66 \%$ and $1.45 \%$ zinc phosphide among oats treated with $1 \%$ anthraquinone $+2 \%$ zinc phosphide, and $2 \%$ anthraquinone $+2 \%$ zinc phosphide, respectively. We observed 24-37\% repellency during a concentration-response test with black-tailed prairie dogs offered corn seeds treated with $0.5-4 \%$ anthraquinone (target concentrations; wt/wt). Thus, anthraquinone may affect consumption of repellent-treated rodenticide baits for black-tailed prairie dogs. Supplemental performance testing and field efficacy studies (e.g., $0.25-0.5 \%$ anthraquinone and $2 \%$ zinc phosphide, actual concentrations; wt/wt) are necessary for further development of an efficacious, bird-repellent rodenticide bait.
\end{abstract}

Published by Elsevier B.V.

\section{Introduction}

Zinc phosphide $\left(\mathrm{Zn}_{3} \mathrm{P}_{2}\right.$; CAS No. 1314-84-7) is an acute toxicant that is used as a rodenticide in Africa (Cudjoe, 1994; Keith and Bruggers, 1998; Mwanjabe et al., 2002), Asia (Ershadi et al., 2005; Parshad, 1999), Australia (Mutze and Sinclair, 2004), Europe (Jacob et al., 2010), and North America (Marsh, 1987). Zinc phosphide can be legally applied in the United States of America to control wild

\footnotetext{
* Corresponding author. Tel.: +1970 266 6136; fax: +1 9702666138 . E-mail address: Scott.J.Werner@aphis.usda.gov (S.J. Werner).
}

rodents (e.g., prairie dogs [Cynomys spp.], voles [Microtus spp.], mice [Peromyscus spp., Mus musculus], ground squirrels [Citellus spp., Spermophilus spp., Urocitellus spp.], pocket gophers [Geomys spp., Thomomys spp., Pappogeomy spp.]) that cause damage to rangelands, golf courses, and agricultural crops such as wheat, grasses grown for seed, nursery products, and berries.

From 2005 to 2008, two instances of suspected nontarget take, or non-target mortalities of wild birds were reported in the USA (Stinebaugh et al., 2005; Dennehy et al., 2008). In August 2005, 47 dead geese (mostly cackling geese [Branta hutchinsii]) were found in the Willamette Valley of Oregon; zinc phosphide was suspected as the 
cause of death (Stinebaugh et al., 2005). From 11 to 16 April 2008, 67 geese were found dead at Staats Lake in Keizer, Oregon. Zinc phosphide was detected in five of six samples collected from the Staats Lake carcasses (Dennehy et al., 2008). Although the Oregon Department of Agriculture requires below-ground application of zinc phosphide on grasses grown for seed from 1 September through 30 April, it is possible that wild birds consume toxic baits associated with field rodenticide applications. Field applications of zinc phosphide have also caused non-target take of partridges (Perdix perdix; Janda and Bosseova, 1970), Corvids (Tkadlec and Rychnovsky, 1990), California quail (Callipepla californica; Ramey and Sterner, 1995), and wild turkeys (Meleagris gallopavo; Poppenga et al., 2005).

Chemical repellents provide a non-lethal alternative for management of agricultural depredation caused by wild birds (Werner et al., 2005, 2007, 2008a,b, 2010). Day et al. (2003) found that a combination of d-pulegone (CAS No. 89-82-7) and an anthraquinone-based repellent (9,10anthraquinone; CAS No. 84-65-1) effectively deterred non-target robins (Petroica australis longipes) from feeding on placebo, pest-control baits in captivity. Anthraquinone concentrations of $1450 \mathrm{ppm}$ and $10,450 \mathrm{ppm}$ also reduced Canada goose (B. canadensis) and ring-necked pheasant consumption of treated corn seeds by $\geq 80 \%$, respectively (Werner et al., 2009). Thus, we were interested to test anthraquinone-conditioned avoidance to reduce take of non-target birds from zinc phosphide rodenticide applications. Our objectives were to evaluate (1) repellent efficacy for non-target birds and (2) rodenticide efficacy for a targeted rodent (black-tailed prairie dog).

In collaboration with Arkion ${ }^{\mathrm{TM}}$ Life Sciences (New Castle, DE, USA), we conducted captive experiments to (1) determine sufficient concentrations of anthraquinone to reduce Canada goose consumption of placebo rodenticide baits (anthraquinone present, zinc phosphide absent) and (2) investigate repellency and potential toxicity of anthraquinone-treated baits for Canada geese (anthraquinone present, zinc phosphide present). In collaboration with the South Dakota Department of Agriculture (Pierre, SD, USA), we conducted laboratory performance experiments with horned larks, ring-necked pheasants, and black-tailed prairie dogs. Our horned lark and ringnecked pheasant experiments were designed to investigate repellency and potential toxicity of anthraquinone-treated baits (anthraquinone present, zinc phosphide present). We selected these avian subjects for our study because they are common, ground-dwelling cohabitants of sites treated with zinc phosphide to control prairie dog populations (Apa et al., 1991; Smith and Lomolino, 2004). Our prairie dog experiments were designed to (1) investigate toxicity and potential repellency of anthraquinone-treated baits (anthraquinone present, zinc phosphide present) and (2) determine repellency of anthraquinone-treated corn seeds (anthraquinone present, zinc phosphide absent).

\section{Materials and methods}

We conducted eight experiments at the National Wildlife Research Center (NWRC) in Fort Collins, CO, USA. We used a no-choice paradigm for our experiments to maximize opportunity for consumption of treated baits and alleviate potential confounding via concurrent provision of untreated baits during the test. All experimental subjects were quarantined at NWRC for at least 14 days prior to our experiments. Water was removed from cages during periods of zinc phosphide exposure to reduce exposure of test subjects and personnel to phosphine gas; else, water was provided ad libitum to all subjects. The capture, care, and use of experimental subjects were approved by the NWRC animal care and use committee (Study Protocols QA-1574, QA-1655, QA-1659; S.J. Werner - Study Director).

We monitored all subjects throughout each of our experiments to qualitatively observe overt signs of zinc phosphide toxicosis. Overt signs of zinc phosphide toxicosis may include excitement, agitation (Clarkson, 1991), unconsciousness, diarrhea, rales, restlessness (Ecobichon, 1991), lethargy, and sternal or lateral recumbency. Onset of clinical signs of zinc phosphide toxicosis is variable but occurs most often within $4 \mathrm{~h}$ post-ingestion (Casteel and Bailey, 1986); time-to-death was unknown for our test subjects. We comparatively monitored all subjects offered baits treated with zinc phosphide for overt signs of toxicosis at 1-h intervals for a minimum of $4 \mathrm{~h}$ subsequent to the daily removal of baits. Interventional euthanasia was not required during any of our experiments.

Anthraquinone concentrations among treated pellets used for our Canada goose experiments were determined using a gas chromatograph/mass spectrograph (Hacco, Inc., Randolph, WI, USA). Anthraquinone concentrations among oat baits used for all other experiments were determined via high performance liquid chromatography (South Dakota State University, Brookings, SD, USA). Zinc phosphide concentrations were quantified among treated oat baits using atomic absorption by South Dakota State University and head space analysis of $\mathrm{PH}_{3}$ by NWRC (Table 1 ).

Table 1

Anthraquinone $(\mathrm{AQ})$ and zinc phosphide $\left(\mathrm{Zn}_{3} \mathrm{P}_{2}\right)$ concentrations quantified by Oscar E. Olson Biochemistry Laboratories (South Dakota State University; Brookings, SD, USA) and the Analytical Services Project of the National Wildlife Research Center (Fort Collins, CO, USA) among rodenticide oat baits used for laboratory performance testing.

\begin{tabular}{llll}
\hline Laboratory & Target concentration & Actual concentration & Date \\
\hline South Dakota State University & $1 \% \mathrm{AQ}$ (Lot I) & $1.12 \% \mathrm{AQ}$ & Report: 15 September 2009 \\
South Dakota State University & $2 \% \mathrm{AQ}$ (Lot H) & $1.88 \% \mathrm{AQ}$ & Report: 15 September 2009 \\
South Dakota State University & $1 \% \mathrm{AQ}+2 \% \mathrm{Zn}_{3} \mathrm{P}_{2}$ (Lot 0905) & $0.916 \% \mathrm{AQ}+2.09 \% \mathrm{Zn}_{3} \mathrm{P}_{2}$ & Report: $7 \mathrm{May} 2009$ \\
National Wildlife Research Center & $1 \% \mathrm{AQ}+2 \% \mathrm{Zn}_{3} \mathrm{P}_{2}$ & $1.66 \% \mathrm{Zn} \mathrm{P}_{2}$ & $\mathrm{Zn} \mathrm{n}_{3} \mathrm{P}_{2}$ analysis: $\mathrm{June} 2010$ \\
South Dakota State University & $2 \% \mathrm{AQ}+2 \% \mathrm{Zn}_{3} \mathrm{P}_{2}$ (Lot F) & $2.22 \% \mathrm{AQ}+2.02 \% \mathrm{Zn}_{3} \mathrm{P}_{2}$ & Report: $28 \mathrm{August} 2009$ \\
South Dakota State University & $2 \% \mathrm{AQ}+2 \% \mathrm{Zn}_{3} \mathrm{P}_{2}$ (Lot G) & $1.80 \% \mathrm{AQ}+1.88 \% \mathrm{Zn}_{3} \mathrm{P}_{2}$ & Report: $15 \mathrm{September} \mathrm{2009}$ \\
National Wildlife Research Center & $2 \% \mathrm{AQ}+2 \% \mathrm{Zn}_{3} \mathrm{P}_{2}$ (Lot G) & $1.45 \% \mathrm{Zn} \mathrm{P}_{2}$ & $\mathrm{Zn} \mathrm{n}_{2}$ analysis: 2 June 2010 \\
\hline
\end{tabular}


Table 2

Treatment schedule for eight experiments regarding consumption of anthraquinone-treated (AQ) zinc phosphide rodenticide baits ( $\mathrm{n}_{3} \mathrm{P}_{2}$ ) by non-target birds and black-tailed prairie dogs (target rodent).

\begin{tabular}{|c|c|c|c|c|}
\hline Subject & Experiment & Treatment group $(n)$ & $\mathrm{AQ}(\%)$ & $\mathrm{Zn}_{3} \mathrm{P}_{2}(\%)$ \\
\hline \multirow[t]{7}{*}{ Canada goose } & 1 & $1(8)$ & 0.1 & 0 \\
\hline & & $2(8)$ & 1 & 0 \\
\hline & & $3(8)$ & 5 & 0 \\
\hline & 2 & $1(10)$ & 0 & 0 \\
\hline & & $2(10)$ & 2.6 & 2 \\
\hline & 3 & $1(10)$ & 1 & 0 \\
\hline & & $2(10)$ & 1 & 2 \\
\hline \multirow[t]{4}{*}{ Ring-necked pheasant } & 1 & 1 (10 cages) & 0 & 0 \\
\hline & & 2 (10 cages) & 2 & 2 \\
\hline & 2 & $1(8)$ & 1 & 0 \\
\hline & & $2(7)$ & 1 & 2 \\
\hline \multirow[t]{3}{*}{ Horned lark } & 1 & $1(12)$ & 0 & 0 \\
\hline & & $2(11)$ & 1 & 2 \\
\hline & & $3(13)$ & 2 & 2 \\
\hline \multirow[t]{10}{*}{ Black-tailed prairie dog } & 1 & $1(10)$ & 0 & 0 \\
\hline & & $2(10)$ & 2 & 0 \\
\hline & & $3(10)$ & 2 & 2 \\
\hline & & $4(9)$ & 1 & 0 \\
\hline & & $5(10)$ & 1 & 2 \\
\hline & 2 & $1(9)$ & 0.5 & 0 \\
\hline & & $2(9)$ & 1 & 0 \\
\hline & & $3(9)$ & 2 & 0 \\
\hline & & $4(9)$ & 3 & 0 \\
\hline & & $5(8)$ & 4 & 0 \\
\hline
\end{tabular}

\subsection{Canada goose experiments}

We conducted three experiments with Canada geese to evaluate repellency of anthraquinone-treated zinc phosphide baits (Prozap ${ }^{\circledR}$ pellets; Hacco, Inc.). We live-captured 64 experimentally naïve Canada geese (adult males and females) in northern Colorado. We used plastic food bowls $(34 \mathrm{~cm}$ diameter) to offer the test diet within outdoor aviaries. The outdoor aviaries consist of a wire meshsided structure that contains 20 cages $(3 \mathrm{~m} \times 3 \mathrm{~m} \times 2.4 \mathrm{~m}$ ) designed to hold waterfowl in an outdoor environment. Geese were visually isolated among individual cages in each of two rows. Our first experiment was designed to identify sufficient anthraquinone concentrations to reduce Canada goose consumption of placebo rodenticide baits. Our second experiment was designed to evaluate repellency of pelletized baits treated with $2.6 \%$ anthraquinone and $2 \%$ zinc phosphide. Our third experiment was designed to evaluate repellency of pelletized baits treated with $1 \%$ anthraquinone and $2 \%$ zinc phosphide.

\subsubsection{Test procedure}

For the first experiment, we offered three groups of individually caged, experimentally naïve Canada geese $(N=24$ males and females; Table 2) $100 \mathrm{~g}$ of placebo Prozap pellets ( $0 \%$ zinc phosphide) treated with $0.1 \%$, $1 \%$, or $5 \%$ anthraquinone (Hacco, Inc.) at $07: 00 \mathrm{~h}$, daily for four days (Monday-Thursday). Subsequent analytical chemistry indicated that these pellets contained $1300 \mathrm{ppm}$ anthraquinone, $4100 \mathrm{ppm}$ anthraquinone, and 27,000 ppm anthraquinone, respectively. We provided a maintenance diet from 16:00 to 07:00 h, daily. Pellet consumption was measured $( \pm 0.1 \mathrm{~g})$ at $07: 00 \mathrm{~h}$ on Tuesday-Friday.
During the second experiment, we provided two groups of individually caged, experimentally naïve Canada geese $(N=20$ males and females, experimentally naïve; Table 2) with $100 \mathrm{~g}$ of Prozap pellet baits treated with $0 \%$ or $2.6 \%$ anthraquinone and $0 \%$ or $2 \%$ zinc phosphide from $06: 00$ to 12:00 h, daily for four days (Monday-Thursday). We provided the maintenance diet from 12:00 to 06:00 h, daily. Pellets were removed and consumption was measured $( \pm 0.1 \mathrm{~g})$ at $12: 00 \mathrm{~h}$ on Monday-Thursday.

For the third experiment, we provided two groups individually caged, experimentally naïve Canada geese $(N=20$ males and females, experimentally naïve; Table 2) with $100 \mathrm{~g}$ of Prozap pellets treated with $1 \%$ anthraquinone and $0 \%$ or $2 \%$ zinc phosphide on the north side of each cage from 07:00 to $12: 00 \mathrm{~h}$, daily for five days (Monday-Friday). We provided the maintenance diet on the south side of each cage, daily. Pellets were removed and consumption was measured $( \pm 0.1 \mathrm{~g})$ at $12: 00 \mathrm{~h}$ on Monday-Friday.

\subsection{Ring-necked pheasant experiments}

We conducted two experiments with ring-necked pheasants to evaluate repellency of commercial oat baits (South Dakota Department of Agriculture, Pierre) treated with $1 \%$ or $2 \%$ anthraquinone and $2 \%$ zinc phosphide. We purchased 95 experimentally naïve ring-necked pheasants (adult males) from a commercial game farm in northern Colorado. We used plastic food bowls (34 cm diameter) to offer the test diet within a flight pen. The 0.4-ha flight pen consists of a wire fence-sided structure that contains ten cages $(6.2 \mathrm{~m} \times 4.0 \mathrm{~m} \times 1.8-3.1 \mathrm{~m})$ designed for feeding experiments in an outdoor environment. Pheasants were not visually isolated among individual cages; we did not account for allelomimetic behavior among test subjects. 


\subsubsection{Test procedure}

Our first experiment ( $N=80$ experimentally naïve ringnecked pheasants) was conducted in two replicate trials ( $n=$ five untreated + five treated cages per trial; four pheasants per cage). For Trial 1, we provided all pheasants with $200 \mathrm{~g}$ of untreated oats or $200 \mathrm{~g}$ of oats treated $2 \%$ anthraquinone and $2 \%$ zinc phosphide on the west side of each cage from 08:00 to $13: 00 \mathrm{~h}$, daily for five days (Table 2 ). We provided a maintenance diet on the east side of each cage from 13:00 to 08:00 h, daily. Oats were removed and consumption was measured $( \pm 0.1 \mathrm{~g})$ at 13:00 h, daily. For Trial 2, we repeated procedures of Trial 1 with 40, experimentally naïve pheasants.

For the second experiment, we provided two groups of ring-necked pheasants ( $N=15$, experimentally naïve) with $100 \mathrm{~g}$ of oats treated with $1 \%$ anthraquinone and $0 \%$ or $2 \%$ zinc phosphide on the north side of each cage from 07:00 to $12: 00 \mathrm{~h}$, daily for five days (Monday-Friday; Table 2). We provided the maintenance diet on the south side of each cage, daily. Oats were removed and consumption was measured $( \pm 0.1 \mathrm{~g})$ at $12: 00 \mathrm{~h}$ on Monday-Friday.

\subsection{Horned lark experiment}

We conducted one experiment with horned larks to evaluate repellency of commercial oat baits (South Dakota Department of Agriculture, Pierre) treated with $1 \%$ or $2 \%$ anthraquinone and $2 \%$ zinc phosphide. We live-captured 36 experimentally naïve horned larks (adult males and females) in northern Colorado for our experiment. We used ceramic food bowls ( $8 \mathrm{~cm}$ diameter) to offer the test diet within the small-bird testing facility. The small-bird testing facility consists of a wire mesh-sided structure that contains 66 cages $(0.9 \mathrm{~m} \times 1.8 \mathrm{~m} \times 0.9 \mathrm{~m})$ designed for choice and no-choice feeding experiments with individual birds in an outdoor environment. Larks were visually isolated among all cages; only the top $30 \mathrm{~cm}$ of all cages were visible between each of two rows of cages.

\subsubsection{Test procedure}

We provided three groups of horned larks (males and females) with $30 \mathrm{~g}$ of oat baits treated with $0-2 \%$ anthraquinone and $0 \%$ or $2 \%$ zinc phosphide on the north side of each cage from 07:00 to $12: 00 \mathrm{~h}$, daily for five days (Monday-Friday; Table 2). We provided a maintenance diet on the south side of each cage, daily. Oats were removed and consumption was measured $( \pm 0.1 \mathrm{~g})$ at $12: 00 \mathrm{~h}$ on Monday-Friday.

\subsection{Black-tailed prairie dog experiments}

We conducted two experiments with black-tailed prairie dogs to evaluate (1) toxicity of commercial oat baits (South Dakota Department of Agriculture, Pierre) treated with $1 \%$ or $2 \%$ anthraquinone and $2 \%$ zinc phosphide and (2) repellency of corn seeds treated with $0.5-4 \%$ anthraquinone. We live-captured 49 experimentally naïve black-tailed prairie dogs (adult males and females) in northern Colorado. These subjects were used for both of our experiments. We used hanging feeders $(15 \mathrm{~cm} \times 10 \mathrm{~cm} \times 23 \mathrm{~cm})$ to offer the test diet in an indoor testing facility. The indoor testing facility (light $06: 00-18: 00 \mathrm{~h}, 15^{\circ} \mathrm{C}$ ) consists of a cement room $(8.4 \mathrm{~m} \times 9.5 \mathrm{~m} \times 6.1 \mathrm{~m})$ that contains seven racks of 56 individual cages $(60 \mathrm{~cm} \times 45 \mathrm{~cm} \times 32 \mathrm{~cm})$ designed for rodent experiments. Prairie dogs were visually isolated among individual cages.

\subsubsection{Test procedure}

For the first experiment, we provided five groups of black-tailed prairie dogs $(N=49$ males and females; Table 2) with $100 \mathrm{~g}$ of oats treated with $0-2 \%$ anthraquinone and $0 \%$ or $2 \%$ zinc phosphide from 07:00 to $12: 00 \mathrm{~h}$, daily for five days (Monday-Friday). The maintenance diet was presented in each cage from 12:00 to 07:00 h, daily. Oats were removed and consumption was measured $( \pm 0.1 \mathrm{~g})$ at $12: 00 \mathrm{~h}$ on Monday-Friday.

Subsequent to our first experiment, we conducted a concentration-response experiment with an anthraquinone-based repellent $\left(\right.$ Avipel $^{\circledR}$, a.i. 50\% 9,10anthraquinone; Arkion Life Sciences, New Castle, DE) to determine anthraquinone repellency for black-tailed prairie dogs ( $N=44$ males and females; Table 2). During a 3-day pre-test (Monday-Wednesday), we offered one bowl (untreated whole corn) in individual cages at 08:00 h, daily. Prairie dogs were ranked based upon pre-test consumption and assigned to one of five treatment groups at the conclusion of the pre-test such that each group was similarly populated with subjects that exhibited high-low daily consumption. We randomly assigned repellent treatments among groups. During the 1-day test (Thursday), we offered one bowl (repellent-treated whole corn) at 08:00 h. Consumption of treated corn seeds was measured $( \pm 0.1 \mathrm{~g})$ at $08: 00 \mathrm{~h}$ on Friday.

\subsection{Data analyses}

The dependent measure for our laboratory performance experiments with Canada geese, ring-necked pheasants, horned larks, and black-tailed prairie dogs was average (i.e., daily) test consumption of treated and untreated rodenticide baits. After successfully conducting Levene's test for equal variances $(\alpha=0.05)$, consumption data for each experiment were subjected to a repeated measures ANOVA using a mixed model (SAS v9.2). The random effect of our model was subjects (or cages of ring-necked pheasants), the between-subjects effect was treatment group, and the within-subject effect was test day. We used Welch's ANOVAs to analyze experiments associated with heteroscedastic consumption data (Zar, 1999). We analyzed the group effect and the group-by-day interaction. We used Tukey's tests to separate means of ANOVA effects $(\alpha=0.05)$ and descriptive statistics $(\bar{x} \pm$ S.E.M. $)$ to summarize consumption of treated and untreated rodenticide baits.

The dependent measure for our anthraquinone concentration-response experiment with black-tailed prairie dogs was percent repellency (i.e., test consumption of anthraquinone-treated corn seeds relative to average, pre-test consumption of untreated seeds). We used non-linear regression procedures (SAS v9.2) to 
analyze repellency as a function of target anthraquinone concentration.

\section{Results}

\subsection{Canada goose experiments}

During our first experiment with Canada geese, we observed greater consumption of placebo pellets $(0 \%$ zinc phosphide) treated with $1300 \mathrm{ppm}$ anthraquinone than those treated with $4100 \mathrm{ppm}$ or $27000 \mathrm{ppm}$ anthraquinone $\left(F_{2,82}=5.24, P=0.007\right)$. We observed no group-by-day interaction during our first experiment $\left(F_{9,82}=0.41, P=0.924\right)$. Geese consumed an average of $7.0 \mathrm{~g}$ of pellets treated with $1300 \mathrm{ppm}$ anthraquinone, and $0 \mathrm{~g}$ of pellets treated with $4100 \mathrm{ppm}$ or $27,000 \mathrm{ppm}$ anthraquinone per day (Tukey $P<0.05$ ). Thus, we used pellets treated with $26,000 \mathrm{ppm}$ anthraquinone for our second experiment.

We observed no goose mortality and no overt signs of zinc phosphide toxicosis during our second experiment. Geese consumed an average of $0 \mathrm{~g}$ of baits treated with $2.6 \%$ anthraquinone and $2 \%$ zinc phosphide, and $3.3 \mathrm{~g}$ of untreated baits per day $\left(F_{1,9}=4.33, P=0.067\right)$. We observed no group-by-day interaction during our second experiment $\left(F_{6,54}=0.57, P=0.749\right)$.

During our third experiment, geese consumed an average of $0.1 \pm 0.0 \mathrm{~g}$ of baits treated with $1 \%$ anthraquinone and $2 \%$ zinc phosphide, and $0.1 \pm 0.0 \mathrm{~g}$ of baits treated with $1 \%$ anthraquinone and $0 \%$ zinc phosphide per day. We observed no goose mortality and no overt signs of zinc phosphide toxicosis during our third experiment.

\subsection{Ring-necked pheasant experiments}

During our first experiment with ring-necked pheasants, we observed no pheasant mortality, no overt signs of zinc phosphide toxicosis, and greater consumption of untreated oat baits ( $0 \%$ anthraquinone and $0 \%$ zinc phosphide) than those treated with $2 \%$ anthraquinone and $2 \%$ zinc phosphide $\left(F_{1,90}=30.70, P<0.001\right)$. Pheasants consumed an average of $9.3 \mathrm{~g}$ of untreated baits, and $0 \mathrm{~g}$ of baits treated with $2 \%$ anthraquinone and $2 \%$ zinc phosphide. We did not observe a group-by-day interaction during our first experiment $\left(F_{8,90}=1.74, P=0.099\right)$.

We observed no pheasant mortality, no overt signs of zinc phosphide toxicosis, and no difference between consumption of oat baits treated with $1 \%$ anthraquinone and $0 \%$ zinc phosphide versus those treated with $1 \%$ anthraquinone and $2 \%$ zinc phosphide during our second experiment $\left(F_{1,6}=5.26, P=0.062\right)$. We did observe a group-by-day interaction $\left(F_{8,52}=7.56, P<0.001\right)$; pheasants consumed more baits treated with $1 \%$ anthraquinone and $0 \%$ zinc phosphide on tests day 1 than on test days 2-5 (Tukey $P<0.04$ ), and more baits treated with $1 \%$ anthraquinone and $2 \%$ zinc phosphide on tests day 1 than on test days 2-3 (Tukey $P<0.05$ ). Pheasants consumed an average of $0.5 \mathrm{~g}$ of oats treated with $1 \%$ anthraquinone and $0 \%$ zinc phosphide, and $0 \mathrm{~g}$ of oats treated with $1 \%$ anthraquinone and $2 \%$ zinc phosphide. Thus, anthraquinone successfully prevented consumption of $2 \%$ zinc phosphide baits by ring-necked pheasants in captivity.

\subsection{Horned lark experiment}

We observed no mortality and no overt signs of zinc phosphide toxicosis during our horned lark experiment. Larks consumed more untreated oat baits $(0 \%$ anthraquinone and $0 \%$ zinc phosphide) than those treated with $1 \%$ or $2 \%$ anthraquinone and $2 \%$ zinc phosphide $\left(F_{2,165}=149.73, P<0.001\right)$. We also observed a group-byday interaction $\left(F_{12,165}=12.16, P<0.001\right)$; larks consumed more untreated baits on test days 2-5 relative to test day 1 (Tukey $P<0.05$ ). Larks consumed an average of $0.4 \mathrm{~g}$ of untreated oats, and $0 \mathrm{~g}$ of oats treated with $1 \%$ or $2 \%$ anthraquinone and $2 \%$ zinc phosphide (Tukey $P<0.05)$. Thus, anthraquinone successfully prevented consumption of $2 \%$ zinc phosphide baits by horned larks in captivity.

\subsection{Black-tailed prairie dog experiments}

We observed three mortalities among prairie dogs that consumed $3.9 \mathrm{~g}$ ( $76.3 \mathrm{mg} \mathrm{Zn} \mathrm{Zn}_{3} \mathrm{P}_{2} / \mathrm{kg}\left[2 \% \mathrm{Zn}_{3} \mathrm{P}_{2}\right.$ bait assumed]), $5.9 \mathrm{~g}\left(143.6 \mathrm{mg} \mathrm{Zn} \mathrm{P}_{2} / \mathrm{kg}\right)$, and $11.2 \mathrm{~g}(288.5 \mathrm{mg}$ $\mathrm{Zn}_{3} \mathrm{P}_{2} / \mathrm{kg}$; Table 3 ) of oats treated with $2 \%$ anthraquinone and $2 \%$ zinc phosphide. Interestingly, three prairie dogs survived after consuming $2.7 \mathrm{~g}\left(62.4 \mathrm{mg} \mathrm{Zn}_{3} \mathrm{P}_{2} / \mathrm{kg}\right), 4.6 \mathrm{~g}$ (84.2 $\mathrm{mg} \mathrm{Zn} \mathrm{Zn}_{3} / \mathrm{kg}$ ), and $6.8 \mathrm{~g}$ (143.7 $\mathrm{mg} \mathrm{Zn}_{3} \mathrm{P}_{2} / \mathrm{kg}$ ) of oats treated with $2 \%$ anthraquinone and $2 \%$ zinc phosphide on test day 1 . We observed one mortality among prairie dogs exposed to oats treated with $1 \%$ anthraquinone and $2 \%$ zinc phosphide; this prairie dog consumed $6.3 \mathrm{~g}$ of treated oats (166.4 $\mathrm{mg} \mathrm{Zn}_{3} \mathrm{P}_{2} / \mathrm{kg}$; Table 3). Interestingly, one prairie dog survived after consuming $4.3 \mathrm{~g}\left(99.4 \mathrm{mg} \mathrm{Zn}_{3} \mathrm{P}_{2} / \mathrm{kg}\right)$ of oats treated with $1 \%$ anthraquinone and $2 \%$ zinc phosphide on test day 1 , and two additional prairie dogs survived after consuming $4.7 \mathrm{~g}\left(99.3 \mathrm{mg} \mathrm{Zn}_{3} \mathrm{P}_{2} / \mathrm{kg}\right)$ and $7.4 \mathrm{~g}(166.0 \mathrm{mg}$ $\mathrm{Zn}_{3} \mathrm{P}_{2} / \mathrm{kg}$ ) of oats treated with $1 \%$ anthraquinone and $2 \%$ zinc phosphide on test day 2 .

We also observed differences in bait consumption among groups during our first experiment $\left(F_{4,203}=62.13\right.$, $P<0.001)$. On average, prairie dogs consumed more untreated oat baits ( $0 \%$ anthraquinone and $0 \%$ zinc phosphide) than all other bait treatments (Tukey $P<0.05$ ), and more baits treated with $1 \%$ or $2 \%$ anthraquinone and $0 \%$ zinc phosphide than those treated with $1 \%$ or $2 \%$ anthraquinone and $2 \%$ zinc phosphide (Tukey $P<0.05$; Fig. 1 ). We observed no group-by-day interaction during our first experiment $\left(F_{20,203}=0.90, P=0.582\right)$.

We observed 24-37\% repellency during our concentration-response experiment with black-tailed prairie dogs offered corn seeds treated with $0.5-4 \%$ anthraquinone (target concentrations; Fig. 2). Interestingly, repellency was not directly related to tested anthraquinone concentrations $\left(r^{2}=0.210, P=0.438\right)$. Thus, anthraquinone may affect consumption of repellenttreated rodenticide baits for black-tailed prairie dogs. 
Table 3

Consumption ( $\mathrm{mg} / \mathrm{kg}$ ) of anthraquinone-treated $(\mathrm{AQ})$ zinc phosphiderodenticide baits $\left(\mathrm{Zn}_{3} \mathrm{P}_{2}\right)$ by black-tailed prairie dogs (Cynomys ludovicianus).

\begin{tabular}{|c|c|c|c|c|c|c|}
\hline \multirow[t]{2}{*}{ Experiment $^{\mathrm{a}}$} & \multirow[t]{2}{*}{ Statistic $(\mathrm{mg} / \mathrm{kg})$} & \multicolumn{5}{|l|}{ Test day ${ }^{\mathrm{b}}$} \\
\hline & & 1 & 2 & 3 & 4 & 5 \\
\hline \multicolumn{7}{|c|}{ Black-tailed prairie dogs } \\
\hline \multirow{2}{*}{$2 \% A Q+2 \% Z_{3} P_{2}$} & Max. & $209.1(288.5)$ & $21.8(30.1)$ & $42.9(\mathbf{5 9 . 2})$ & $75.1(103.6)$ & $46.8(64.6)$ \\
\hline & Average & $64.5(88.9)$ & $6.3(8.7)$ & $15.0(20.8)$ & $20.5(28.3)$ & $11.6(16.0)$ \\
\hline $1 \% \mathrm{AQ}+2 \% \mathrm{Zn}_{3} \mathrm{P}_{2}$ & Min. & 0 & 0 & 0 & 0 & 0 \\
\hline
\end{tabular}

${ }^{a}$ The actual zinc phosphide concentrations in baits treated with $2 \%$ and $1 \%$ AQ were $1.45 \%$ and $1.66 \%$ zinc phosphide, respectively, upon completion of laboratory performance experiments.

b Consumption statistics in parentheses were calculated by assuming $2 \%$ zinc phosphide concentration. Consumption figures in bold exceed the reported median lethal dose of zinc phosphide for rodents $\left(\operatorname{LD}_{50}=45.7 \mathrm{mg} / \mathrm{kg}\right.$; Clarkson, 2001).

\section{Discussion}

We observed zero mortalities and no overt signs of zinc phosphide toxicosis among 20 Canada geese, 24 horned larks, and 47 ring-necked pheasants offered rodenticide

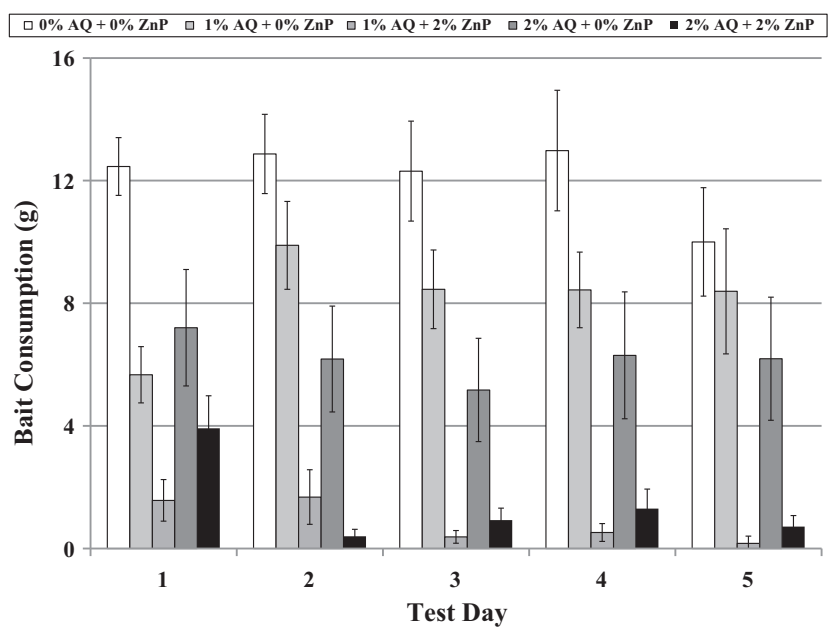

Fig. 1. Mean consumption $( \pm S E)$ of untreated oats versus those treated with $0-2 \%$ anthraquinone (AQ) and $0 \%$ or $2 \%$ zinc phosphide $\left(\mathrm{Zn}_{3} \mathrm{P}_{2}\right)$ among black-tailed prairie dogs (Cynomys ludovicianus).

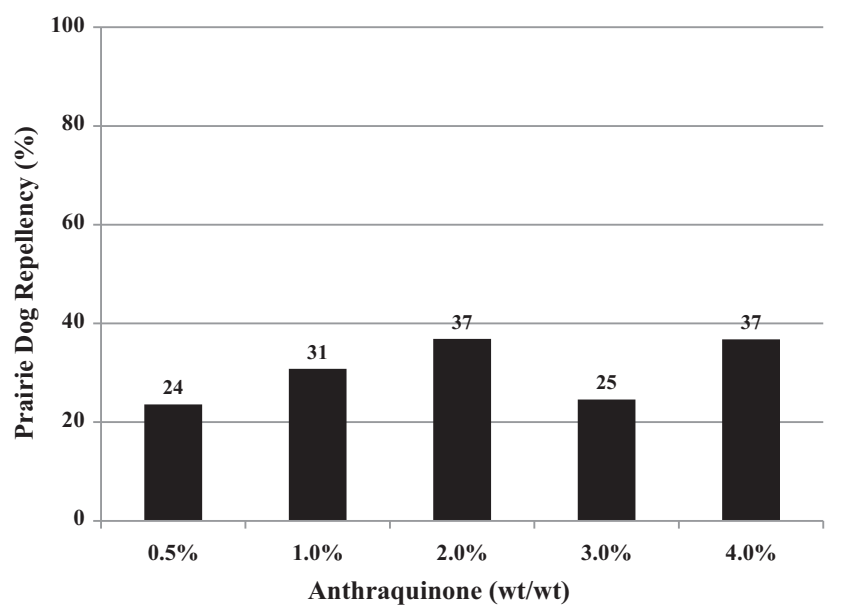

Fig. 2. Mean feeding repellency associated with five concentrations of Avipe ${ }^{\circledR}$ seed treatments (a.i., 50\% 9,10-anthraquinone; Arkion Life Sciences, New Castle, DE, USA) offered to black-tailed prairie dogs (Cynomys ludovicianus). baits treated with 1 or $2 \%$ anthraquinone and $2 \%$ zinc phosphide (target concentrations; wt/wt). After correcting for actual zinc phosphide concentrations quantified upon the conclusion of our experiments (Table 1), we calculated that individual ring-necked pheasants consumed up to $184.7 \mathrm{mg} \mathrm{Zn} \mathrm{Zn}_{2} / \mathrm{kgon}$ day 1 of our second experiment. Thus, previous median lethal dose $\left(\mathrm{LD}_{50}\right)$ estimates for zinc phosphide (e.g., $16 \mathrm{mg} / \mathrm{kg}$ for ring-necked pheasants; Denver Wildlife Research Center, unpublished data) may be unreliable.

We observed $<50 \%$ mortality among black-tailed prairie dogs offered oat baits treated with 1 or $2 \%$ anthraquinone and $2 \%$ zinc phosphide (target concentrations, wt/wt). Rodenticide efficacy may have been affected by indoor testing conditions associated with our first experiment (e.g., temperature range $=13-19^{\circ} \mathrm{C}$ ). By comparison, the average minimum and maximum outside temperatures associated with prairie dog capture locations $\left(40^{\circ} 27^{\prime} \mathrm{N}\right.$, $105^{\circ} 0^{\prime} \mathrm{W}$, Fort Collins, CO, USA) were $1^{\circ} \mathrm{C}$ (range $=-7$ to $8^{\circ} \mathrm{C}$ ) and $15^{\circ} \mathrm{C}$ (range $=6-27^{\circ} \mathrm{C}$ ), respectively. The $\mathrm{LD}_{50}$ of zinc phosphide for rodents is $45.7 \mathrm{mg} \mathrm{Zn} \mathrm{Zn}_{3} / \mathrm{kg}$ (Clarkson, 2001 ). On test day 1 , prairie dogs consumed an average of $64.5 \mathrm{mg} \mathrm{Zn} \mathrm{Zn}_{2} / \mathrm{kg}$ (Table 3) when offered oat baits treated with $2 \%$ anthraquinone and $1.45 \%$ zinc phosphide (actual $\mathrm{Zn}_{3} \mathrm{P}_{2}$ concentration). Thus, we recommend improved formulations of anthraquinone-treated rodenticide baits to maintain efficacious concentrations of the rodenticide active ingredient.

In supplement to chemical repellents, color cues can be used to reduce potential hazards of pesticide applications for non-target birds (Caithness and Williams, 1971; Gionfriddo and Best, 1996; Hartley et al., 1999; Jacob and Leukers, 2008; Mastrota and Mench, 1994). Day et al. (2003) observed feeding deterrence among non-target robins offered pest-control baits treated with a green dye, d-pulegone, and an anthraquinone-based repellent in captivity. Birds can generally distinguish colors ranging from $350 \mathrm{~nm}$ (ultraviolet) to $750 \mathrm{~nm}$ (red; Bowmaker, 1987). Wild birds associate pre- and postingestive consequences with visual cues, and reliably integrate visual and gustatory experience with postingestive consequences to procure nutrients and avoid toxins (Werner et al., 2008c; Werner and Provenza, 2011). Whereas anthraquinone is an emodin purgative (Merck, 1991) and anthraquinone absorbs near-ultraviolet light (300-400 nm; Du et al., 1998) 
that is visible to most birds, anthraquinone is a quintessential avoidance-conditioning agent for wild birds (Werner et al., 2009). Werner and Provenza (2011) suggested that an effective application strategy for avian repellents might include initial applications of a postingestive repellent (e.g., anthraquinone) and subsequent applications of a visual cue with spectral characteristics (e.g., near-ultraviolet absorbance) sufficiently similar to the repellent (Werner, 2009).

\section{Conclusion}

Our study indicates that bird-repellent rodenticide formulations are a promising means of protecting non-target birds from rodenticide applications. Although we observed no mortalities among non-target birds, we observed only $10 \%$ and $30 \%$ mortality among target rodents offered rodenticide baits treated with $1 \%$ and $2 \%$ anthraquinone, respectively. Whereas black-tailed prairie dogs exhibited some repellency for $0.5-4 \%$ anthraquinone during our concentration-response experiment and anthraquinone threshold concentrations have been recently estimated for non-target birds (e.g., 0.145\% anthraquinone for Canada geese; Werner et al., 2009), we recommend additional development and evaluation of anthraquinone-treated rodenticide baits to reduce non-target consumption of rodenticide baits by wild birds. Supplemental performance testing and field efficacy studies are needed to evaluate response of non-target birds and target rodents offered baits treated with $0.25-0.5 \%$ anthraquinone and $2 \%$ zinc phosphide (i.e., actual concentrations; wt/wt).

\section{Acknowledgements}

Arkion Life Sciences (New Castle, DE, USA) provided financial support for our experiments with Canada geese. The South Dakota Department of Agriculture (Pierre, SD, USA) provided financial support for our experiments with horned larks, ring-necked pheasants, and black-tailed prairie dogs. We thank Michael Blume (South Dakota Department of Agriculture) for coordinating the formulation and transportation of oat baits for our laboratory performance experiments. Corporate collaborations do not imply endorsement by the United States Department of Agriculture. We thank D. Goldade (NWRC, Fort Collins, CO, USA), R. Larson (South Dakota State University, Brookings, SD, USA), and L. Song (Hacco, Inc., Randolph, WI, USA) for providing analytical chemistry services. We sincerely appreciate the technical assistance provided by B. Larson during our prairie dog experiments, and the professional care provided by the NWRC animal care staff for all experimental subjects during quarantine and holding. We also thank K.E. Horak and M.E. Tobin for their thoughtful review of our manuscript.

\section{References}

Apa, A.D., Uresk, D.W., Linder, R.L., 1991. Impacts of black-tailed prairie dog rodenticides on nontarget passerines. Great Basin Nat. 51, 301-309. Bowmaker, J.K., 1987. Avian color vision and the environment. Proc. Int. Ornith. Congr. 19, 1284-1294.
Caithness, T.A., Williams, G.R., 1971. Protecting birds from poison baits. N. Z. J. Agric. 12, 38-43.

Casteel, S.W., Bailey, E.M., 1986. A review of zinc phosphide poisoning. Vet. Hum. Toxicol. 28, 151-154.

Clarkson, T.W., 1991. Inorganic and organometal pesticides. In: Hayes, W.J., Laws, E.R. (Eds.), Handbook of PesticideToxicology. Academic Press, NY, USA, pp. 10-161.

Clarkson, T.W., 2001. Inorganic and organometal pesticides. In: Krieger, R. (Ed.), Handbook of Pesticide Toxicology. Academic Press, San Diego, CA, USA, pp. 1357-1428.

Cudjoe, A.R., 1994. Vertebrate pests of cassava in Africa and their control. Afr. Crop Sci. J. 2, 497-503.

Day, T.D., Matthews, L.R., Waas, J.R., 2003. Repellents to deter New Zealand's North Island robin Petroica australis longipes from pest control baits. Biol. Conserv. 114, 309-316.

Dennehy, M., Pokarney, B., Jewett, J., 2008. Dead geese test positive for rodenticide. Oregon Dept. Fish Wildl. News Release, April 21, 2008.

Du, H., Fuh, R.A., Li, J., Corkan, A., Lindsey, J.S., 1998. PhotochemCAD: a computer aided design and research tool in photochemistry. Photochem. Photobiol. 68, 141-142.

Ecobichon, D.J., 1991. Toxic effects of pesticides. In: Amdur, M.O., Doull, J., Klassen, C.D. (Eds.), Casarett and Doull's Toxicology: The Basic Science of Pesticides. , fourth ed. Pergamon Press, NY, USA.

Ershadi, M-R.Y., Zahraei-Ramazani, A-R., Akhavan, A-A., Jalali-Zand, AR., Abdoli, H., Nadim, A., 2005. Rodent control operations against zoonotic cutaneous leishmaniasis in rural Iran. Ann. Saudi Med. 25, 309-312.

Gionfriddo, J.P., Best, L.B., 1996. Grit color selection by house sparrows and northern bobwhites. J. Wildl. Manage. 60, 836-842.

Hartley, L.J., O'Connor, C.E., Waas, J.R., Matthews, L.R., 1999. Colour preferences in North Island robins (Petroica australis): implications for deterring birds from poisonous baits. N. Z. J. Ecol. 23, 255-260.

Jacob, J., Budde, M., Leukers, A., 2010. Efficacy and attractiveness of zinc phosphide bait in common voles (Microtus arvalis). Pest Manage. Sci. $66,132-136$.

Jacob, J., Leukers, A., 2008. Preference of birds for zinc phosphide bait formulations. Pest Manage. Sci. 64, 74-80.

Janda, J., Bosseova, M., 1970. The toxic effect of zinc phosphide baits on partridges and pheasants. J. Wildl. Manage. 34, 220-223.

Keith, J.O., Bruggers, R.L., 1998. Review of hazards to raptors from pest control in Sahelian Africa. J. Raptor Res. 32, 151-158.

Marsh, R.E., 1987. Relevant characteristics of zinc phosphide as a rodenticide. Great Plains Wildl. Dam. Cont. 8, 70-74.

Mastrota, F.N., Mench, J.A., 1994. Avoidance of dyed food by the northern bobwhite. Appl. Anim. Behav. Sci. 42, 109-119.

Merck, 1991. In: Fraser, C.M., Bergeron, J.A. (Eds.), Merck Veterinary Manual. , seventh ed. Merck \& Co., Inc., USA, p. 1383.

Mutze, G., Sinclair, R., 2004. Efficacy of zinc phosphide, strychnine and chlorpyrifos as rodenticides for the control of house mice in South Australian cereal crops. Wildl. Res. 31, 249-257.

Mwanjabe, P.S., Sirima, F.B., Lusingu, J., 2002. Crop losses due to outbreaks of Mastomys natalensis (Smith, 1834), Muridae, Rodentia in the Lindi Region of Tanzania. Int. Biodeterior. Biodegrad. 49, 133-137.

Parshad, V.R., 1999. Rodent control in India. Int. Pest Manage. Rev. 4, 97-126.

Poppenga, R.H., Ziegler, A.F., Habecker, P.L., Singletary, D.L., Walter, M.K., Miller, P.G., 2005. Zinc phosphide intoxication of wild turkeys (Meleagris gallopavo). J. Wildl. Dis. 41, 218-223.

Ramey, C.A., Sterner, R.T., 1995. Mortality of gallinaceous birds associated with $2 \%$ zinc phosphidebaits for control of voles in alfalfa. Int. Biodeterior. Biodegrad. 36, 51-64.

Smith, G.A., Lomolino, M.V., 2004. Black-tailed prairie dogs and the structure of avian communities on the shortgrass plains. Oecologia 138, 592-602.

Stinebaugh, J., Jewett, J., Patte, D., 2005. Goose die-Off in Willamette Valley under investigation: Agents suspect the geese may have been poisoned. U.S. Fish Wildl. Service News Release, 05-79.

Tkadlec, E., Rychnovsky, B., 1990. Residues of $\mathrm{Zn}_{3} \mathrm{P}_{2}$ in the common vole (Microtus arvalis) and secondary poisoning hazards to predators. Folia Zool. 39, 147-156.

Werner, S.J. 2009. Ultraviolet strategy for avian repellency, U.S.A. Patent Application \#12/652,944.

Werner, S.J., Carlson, J.C., Tupper, S.K., Santer, M.M., Linz, G.M., 2009. Threshold concentrations of an anthraquinone-based repellent for Canada geese, red-winged blackbirds, and ring-necked pheasants. Appl. Anim. Behav. Sci. 121, 190-196. 
Werner, S.J., Cummings, J.L., Pipas, P.A., Tupper, S.K., Byrd, R.W., 2008a. Registered pesticides and citrus terpenes as blackbird repellents for rice. J. Wildl. Manage. 72, 1863-1868.

Werner, S.J., Cummings, J.L., Tupper, S.K., Goldade, D.A., Beighley, D., 2008b. Blackbird repellency of selected registered pesticides. J. Wildl. Manage. 72, 1007-1011.

Werner, S.J., Cummings, J.L., Tupper, S.K., Hurley, J.C., Stahl, R.S., Primus, T.M., 2007. Caffeineformulation for avian repellency. J. Wildl. Manage. $71,1676-1681$.

Werner, S.J., Homan, H.J., Avery, M.L., Linz, G.M., Tillman, E.A., Slowik, A.A., Byrd, R.W., Primus, T.M., Goodall, M.J., 2005. Evaluation of Bird
Shield ${ }^{\mathrm{TM}}$ as a blackbird repellent in ripening rice and sunflower fields. Wildl. Soc. Bull. 33, 251-257.

Werner, S.J., Kimball, B.A., Provenza, F.D., 2008c. Food color, flavor, and conditioned avoidance among red-winged blackbirds. Physiol. Behav. $93,110-117$.

Werner, S.J., Linz, G.M., Tupper, S.K., Carlson, J.C., 2010. Laboratory efficacy of chemical repellents for reducing blackbird damage in rice and sunflower crops. J. Wildl. Manage. 74, 1400-1404.

Werner, S.J., Provenza, F.D., 2011. Reconciling sensory cues and varied consequences of avian repellents. Physiol. Behav. 102, 158-163.

Zar, J.H., 1999. Biostatistical Analysis, fourth ed. Prentice-Hall, Inc., USA. 